\title{
Outlook of future implementation of PEMFC and SOFC onboard cruise ships
}

\author{
Marco Gianni ${ }^{1,2}$, Andrea Pietra ${ }^{1,2}$, and Rodolfo Taccani ${ }^{2 *}$ \\ ${ }^{1}$ Fincantieri S.p.A., Functional Design - Electrical Systems Unit, 34123 Trieste, Italy \\ ${ }^{2}$ Università degli studi di Trieste, Engineering and Architecture Department (DIA), 34127 Trieste, Italy
}

\begin{abstract}
According to third IMO GHG Study shipping is responsible of about 2,6\% of world $\mathrm{CO}_{2} \mathrm{e}$ (carbon dioxide equivalent) emissions. The dangerous effect on people is increased because emissions are concentrated in coastal areas. IMO and other bodies are engaged in imposing measures to reduce GHG emissions and improve the overall ship's energy efficiency. There are many technical and operational improvements that can help to reach these goals, but hydrogen and fuel cells remain one of the best candidates to substantially reduce emissions and fuel consumption. This paper gives an outlook of possible fuel cells applications in the marine sector and analyses the potential of Proton Exchange Membrane Fuel Cells (PEMFC) and Solid Oxide Fuel Cells (SOFC) for the on-board installation. The analysis shows the advantages that fuel cells can give in terms of emissions reductions and fuel saving, but also highlights some challenges that designers will face when implementing these technologies on a cruise ship. Both PEMFC and SOFC application in the marine sector suffer of the lack of standards and regulations from IMO and Classification Societies and high acquisition cost. While PEMFC are ready for marine application, SOFC are still in a study phase for on-board implementation. Also, the type of fuel used by these generators and the possibility of heat recovery can influence their application on-board cruise ships.
\end{abstract}

\section{Introduction}

Ships are one of the oldest means of transportation for goods and passengers, as they contributed during history to migrations, commerce, research, defence and humanitarian purposes. From its beginnings to $19^{\text {th }}$ century principal means of marine propulsion were oars and wind. Then engine and turbines using nonrenewable fuels became the most common prime generators of power on-board. For this reason, ship transport became one of the sectors responsible for air pollution. Ship transportation by the way is one of the most carbon efficient method of shipping. The whole transport sector is responsible for $14 \%$ of global $\mathrm{CO}_{2 \mathrm{e}}$ emission [1], but sea trades represented in $201690 \%$ of world total [2] while accounting according to the International Maritime Organization (IMO) approximately $2.1 \%$ of global $\mathrm{CO}_{2 \mathrm{e}}$ in 2012, almost 961 million tonnes $\mathrm{CO}_{2 \mathrm{e}}$. Emissions from ships were also responsible during the period 2007-2012 of an average annual $15 \%$ of global $\mathrm{NO}_{\mathrm{x}}$ emissions (20.9 million tonnes) and $13 \%$ of global $\mathrm{SO}_{\mathrm{x}}$ emissions (11.3 million tonnes) [3]. If we account dead weight tonnes, that measures ship's transport capacity, the global fleet in 2017 was mainly composed by three vessels type: oil tankers, bulk carriers and container ships, as showed in Fig. 1 with blue bars [4]. Red ones indicate each category's percentage of total ships' value.

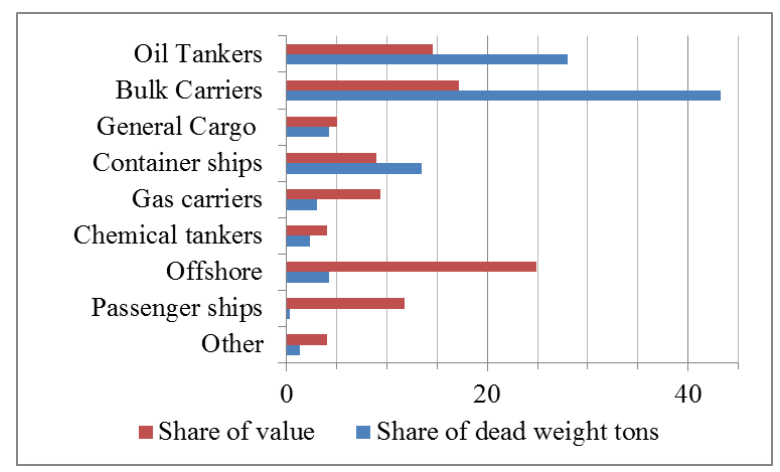

Fig. 1. World fleet by principal vessels type (2017) [4]

To prevent an increase of ship emissions and their environmental impact in the future, from 1973 IMO established mandatory regulations, like the $\mathrm{SO}_{\mathrm{x}}$ and $\mathrm{NO}_{\mathrm{x}}$

\footnotetext{
* Marco Gianni: marco.gianni@phd.units.it; Andrea Pietra: andrea.pietra@phd.units.it; Rodolfo Taccani: taccani@units.it
} 
emission limits in MARPOL Annex VI. These limits became stricter as the years go by, culminating in the mandatory limit of $0.5 \%$ (mass on mass) content of $\mathrm{SO}_{\mathrm{x}}$ in marine fuels from $1^{\text {st }}$ January 2020. Also, IMO has adopted an initial strategy to limit GHG emissions from ship with his Marine Environment Protection Committee (MPEC). The target is to reduce GHG emissions by at least $50 \%$ by 2050 compared to 2008 and also to reduce $\mathrm{CO}_{2}$ emission per transport work by at least $40 \%$ by 2030 , pursuing efforts towards $70 \%$ by 2050, compared to 2008 [5].

In this context, passenger ships represented in 2017 almost $0.3 \%$ of the global fleet if we consider deadweight tons, but $12 \%$ of ship value in dollars, as shown in Fig. 1. For this type of vessel emission requirement could even become stricter in some zones of the planet, like in Norwegian world heritage fjords. The Norwegian Parliament adopted a resolution to impose passenger ship and ferries to navigate with zero emission in that sites as soon as possible, but not later than 2026 [6]. These requirements coming from national or international regulations are forcing shipbuilders and ship owners to consider different fuels and technologies to reduce or even eliminate harmful emissions. Currently, the vast majority of marine engines are fed by Heavy Fuel Oil (HFO), which is the residual part of distillation and cracking process of crude oil: it contains high levels of sulphur and metallic compounds, aromatics and carbon residues, but it's very cost effective. To meet current requirements, ship needs to use more refined fuels with less sulphur content, as Marine Diesel Oil (MDO), Marine Gas Oil (MGO), Low Sulphur HFO (LSHFO), Liquefied Natural Gas (LNG) or to introduce systems to reduce emissions, like scrubbers. These methods can all be considered on a cruise ship, but they reduce payload capacity and increase complexity of design and maintenance of the vessel. For these reasons, ship owners are considering alternative ways for power generation on-board their vessels. In this paper, carbon based fuels are considered as "standard" market products and not as bio-fuels coming from renewable energy sources.

Among these alternatives fuel cells are gaining more interest because they can potentially operate with a wide range of fuel, in particular with hydrogen, allowing a reduction of exhaust emissions, noise and vibration with an efficiency comparable or higher than conventional power plants [7] [8]. By now, fuel cells are used for some years for stationary applications: in the period 2015-2019 almost $200 \mathrm{MW}$ of fuel cell are annually sold each year, especially in USA, Japan and South Korea. In the same period there have been a great raise of fuel cell application for transport, mainly on cars, buses and trains, with more than $900 \mathrm{MW}$ of fuel cell sold in 2019 [9]. In the maritime sector fuel cell has mostly been applied in some demonstrators or at a conceptual level [8]. One fuel cell system already operative and with a lot of years of service is the Proton Exchange Membrane (PEM) air independent propulsion (AIP) system installed on-board submarines Type U212 designed by Germany and Italy in the '90s and with the first unit delivered in 2005.
Fuel cells can help to reduce emission and improve ship efficiency, but they also are costly, and they suffer of the lack of rules and regulation that need to be applied in order to install them on-board. This paper describes the outlook of future implementation of PEMFC and Solid Oxide Fuel cells (SOFC) on-board cruise ships, discussing both advantages and possible challenges that designers and operators will need to face when dealing with this technology. The first part of the paper gives a brief view of the regulatory framework, highlighting the lack of precise requirement. In the second part a possible maritime power plant is described both for PEMFC and SOFC installation, describing the impact in terms of general arrangement layout, auxiliaries needed and improvement of emissions and fuel consumption.

\section{Regulatory framework}

Besides IMO's requirements and strategy for the reduction of ship's emission, there is still uncertainty about rules and standards that need to be followed to install new technologies, like fuel cells, and to store novel fuels, like hydrogen or ammonia, on-board. In 2015 IMO adopted with resolution MSC.391(95) the International Code for ships using gases of other lowflashpoint fuels (IGF Code), but in its preamble it states that:

"The current version of this Code includes regulations to meet the functional requirements for natural gas fuel. [...] In the meantime, for other lowflashpoint fuels, compliance with the functional requirements of this Code must be demonstrated through alternative design." [10]

Some classification societies also developed rules or at least guidelines for the use of fuel cells on-board ships, as shown in Table 1. In that table is also included the only classification society, namely the Nippon Kaiji Kyokai (Class NK), that elaborated guidelines for liquefied hydrogen carriers [11].

Table 1. Classification societies rules about fuel cell (2020)

\begin{tabular}{|c|c|c|}
\hline $\begin{array}{c}\text { Classification } \\
\text { Society }\end{array}$ & Title & Year \\
\hline $\begin{array}{c}\text { American Bureau } \\
\text { of Shipping (ABS) }\end{array}$ & $\begin{array}{c}\text { Guide for Fuel cell power } \\
\text { systems for marine and } \\
\text { offshore applications }\end{array}$ & 2019 \\
\hline $\begin{array}{c}\text { Bureau Veritas } \\
\text { (BV) }\end{array}$ & $\begin{array}{c}\text { Guidelines for Fuel Cell } \\
\text { Systems On-board } \\
\text { Commercial Ships }\end{array}$ & 2009 \\
\hline DNV GL & $\begin{array}{c}\text { Rules for classification of } \\
\text { ships: Part 6 Ch. 2 Sec. 3 }\end{array}$ & 2018 \\
\hline $\begin{array}{c}\text { Korean Register } \\
\text { of Shipping (KR) }\end{array}$ & $\begin{array}{c}\text { Guidance for Fuel Cell } \\
\text { Systems on Board of } \\
\text { Ships }\end{array}$ & 2015 \\
\hline $\begin{array}{c}\text { Registro Italiano } \\
\text { Navale (RINA) }\end{array}$ & $\begin{array}{c}\text { Rules for Fuel Cells } \\
\text { Installation in Ships (FC- } \\
\text { SHIPS) }\end{array}$ & 2018 \\
\hline Nippon Kaiji \\
Kyokai & $\begin{array}{c}\text { Guidance for Liquefied } \\
\text { Hydrogen Carriers }\end{array}$ & 2017 \\
\hline
\end{tabular}

The other rules and guidelines are focused on fuel cells, regardless of their technology and the particular 
fuel used inside them. The general goal is to provide criteria for installation of machinery for essential or nonessential purposes using fuel cells as power generators, while ensuring the same level of safety, dependability and reliability of a conventional fueled ship [12] [13] [14] [15] [16].These rules share many similar requirements, as:

- Definition of Hazardous Areas according to IEC 60079-10-1;

- Minimization of hazardous areas and equipment installed in them;

- Avoiding in these areas the creation of places where gas can accumulate in failure conditions;

- Provision of adequate ventilation to avoid an explosive atmosphere and lack of oxygen in enclosed rooms;

- Installation of adequate gas detection for gases that can be present in enclosed hazardous areas and connecting it with alarm and shutdown system;

- Provision of fire detection and extinction suitable for these applications.

Fuel's pipe in enclosed spaces are an important topic of these guidelines. These regulations are not in accordance with each other because they impose one of the following options:

- Double wall pipes mandatory installation [12];

- Choice between double wall pipes and fully welded pipes combined with a ventilation rate sufficient to dilute gas concentration below flammable range in all leakage scenarios [14] [16];

- Choice between a gas safe fuel cell space, with double wall pipes (not mandatory in [15] for hydrogen) and an ESD-protected FC space, where pipes can be single walled but they must be fully welded and with a ventilation rate sufficient to dilute gas concentration below flammable range in all leakage scenarios [13] [15];

For ABS and DNV-GL every room related to fuel cells and their fuel must be regarded as machinery space of category A according to SOLAS Ch. II-2 for fire protection purposes, instead for RINA just fuel preparation rooms must be categorized in that way. BV and KR identify just compressor room as a machinery space of category A, while stating that the categorization of other rooms depends on the amount of combustible material or fuel available in the space. This is an important project driver because machinery spaces of category A are subjected to particular requests about passive and active fire protection, such as heavier and more expensive insulations, fire detectors and fire dumpers of different type. Each guideline gives precise indication about fire extinguishing system for bunker station and fuel storage rooms, except DNV-GL, but neither of them address a particular fire extinguishing system for fuel cell room. For the FC rooms every regulation specifies that is mandatory to have inside them a fire detection system that needs to be decided on the basis of actual fuel used.

For ABS, DNV-GL and KR, fuel cell rooms are hazardous zones 1 according to IEC 60079-10-1, because they contain possible sources of release of inflammable gases, like pipes if not double walled or fuel cells themselves. BV does not specify which is fuel cell room's classification and RINA considers fuel cell room non-hazardous area during normal operation, but will require equipment to operate following detection of gas leakage to be certified as suitable for zone 1 .

Lack of precise regulations and discordance about specific topics with great importance, like hazardous zones prescriptive classification, not only creates confusion, but also makes more difficult alternative design processes and risk assessments.

\section{Maritime power plant}

Cruise ships were among the first type of vessels to implement electric propulsion on board. With this philosophy, system configuration is based on a power plant where electrical generators moved by internal combustion engines work in parallel on main switchboards, feeding two big classes of users. The first one is related to propulsion, steering and all equipment related to ship safety, like:

- Propulsion electric motors and auxiliaries;

- Engine service equipment;

- Maneuvering thrusters and auxiliaries;

- Navigation and safety systems.

The second purpose of power generation is offering to crew and passengers everything they need, like:

- Comfort: air conditioning, accommodations with private and public services, laundries to wash linen, lighting.;

- Nourishment: different type of restaurants, big galleys to prepare and cook food, big refrigerated rooms to store it, etc.;

- Entertainment: theatres, pools, casinos, cinemas, SPAs etc.

The ship's power plant is normally placed on lowest decks to minimize impact on payload volume and to lower ship's center of gravity. This arrangement increases intact stability of a ship, especially when the vessel is not already inclined (initial stability) [17]. Engine rooms normally occupy at least two decks in height because the average engine mounted on a passenger ship has a height that exceeds vertical distance between two decks. With electric propulsion also engine rooms do not need to be placed near ship's stern, where propellers are placed, but can be moved forward, near longitudinal center of the vessel. Today most cruise ships are fueled by HFO, but this solution is discouraged by strict regulations about emissions and competitive price of natural gas, stored in his liquefied form (LNG). In recent years this fuel has gained popularity in maritime sector, because it lower GHG, SOx and NOx without installing any post-combustion treatment (scrubbers) and a competitive cost compared to traditional solutions [18]. LNG is stored in pressurized independent cryogenic tanks inside the ship 
at about $-160^{\circ} \mathrm{C}$. This interest in alternative solutions to reduce emissions and the proven possibility of installing and operating ships with gaseous fuels are key factors that trigged the possibility of using fuel cells in maritime industry.

\section{Fuel cell systems for ships}

In this context of uncertainty about how to comply with present and future strict limits on harmful emissions in the maritime sector, fuel cells are emerging as a possible solution to generate part of the power required on board.

There are several fuel cell technologies that differ mainly for the type of electrolyte. In the following PEMFC and SOFC are considered for the application on board of cruise ships. PEMFCs are chosen as they are today the most mature technology especially as they are applied in the automotive sector. Even if the technology maturity of SOFCs is lower, they could be of great interest as they offer a higher flexibility in terms of fuel choice.

\subsection{PEMFC}

PEMFC are one of the most utilised fuel cell technologies and their sales have seen a big increase in last years due to their applications in transport sector, especially cars, buses and trains. PEMFCs need pure hydrogen as fuel at the anode and oxygen from air at the cathode and their operating temperature is between 50$100^{\circ} \mathrm{C}$. Their electrical efficiency is between 50 and $60 \%$, and stack power density is between 400 and 2000 $\mathrm{kW} / \mathrm{m}^{3}$ [19][20].PEMFC cost is expected to be relatively high, between 1700 and 2800 $\$ / \mathrm{kW}[21]$,depending the number of units produced per year and stack's size.

Considering the low solubility of hydrogen in water $\left(0.00016 \mathrm{~g}\right.$ of hydrogen in $100 \mathrm{~g}$ of water at $20^{\circ} \mathrm{C}$ and 1 atm [22]), there is the possibility to use by-product water for ship services, like technical water or for steam production. With simple stoichiometric calculations it is possible to obtain an approximation of how much water is produced for a given power output[23].Assuming a single cell voltage of $0.65 \mathrm{~V}$, for each $\mathrm{MWh}$ of electricity, more than $500 \mathrm{~kg}$ of water are produced. A negative aspect of this technology is the fact that low operative temperature makes waste heat recovery more difficult, which could be fundamental to have high energy efficiency ship. Today, main diesel engines do not provide only electric power, but also heat through Exhaust Gas Boilers (EGB) heat recovery system. If this heat source is not enough, Oil Fired Boilers (OFB) produce the amount of vapour needed for various services, like maintain pumpable HFO by warming it up. Obviously, oil fired boilers are a source of $\mathrm{GHG}$ emissions and imagining a zero emission operative mode in navigation or port is not possible without heat production on board, that it is difficult for PEMFC to provide. To resolve this issue, a high temperature fuel cell technology, such as SOFC, could be considered.

\subsection{SOFC}

SOFC are named also high temperature fuel cells because they normally work between $500{ }^{\circ} \mathrm{C}$ and 1000 ${ }^{\circ} \mathrm{C}$, thanks to their electrolyte made with a ceramic porous material. SOFC are typically installed in hundreds of kilowatts power plants. One of the main advantages of this technology is the fuel flexibility given by high operative temperature: SOFC can use LNG, methanol but also hydrogen. Obviously, fuel used influences emissions, which even with LNG are reduced if compared to dual fuel engines, as explained in paragraph 0 . Fuel reforming happens inside fuel cell modules and there is only the need to check inlet composition and purify it according to SOFC's manufacturer. As a matter of fact, ships do not always refuel in the same port facilities and so product composition can change and needs to be checked in order to avoid SOFC degradation. This issue is less important for SOFC than for PEMFC, that require only high-level purity hydrogen as fuel. Electrical efficiency of a SOFC system is between $50 \%$ and $60 \%$, but high temperature allows introducing a heat recovery system so that there could be no need for exhaust gas boilers in some of ship's operative modes. SOFCs have a lower power density compared to PEMFC, nearly half of it (between 8 and $10 \mathrm{~kW} / \mathrm{m}^{3}$, with the same auxiliaries included) not considering heat recovery system. Acquisition cost could vary between 800 and 1900 $\$ / \mathrm{kW}$, depending the number of units produced per year and stack's size [19]. SOFC have a system power density between 8 and $10 \mathrm{~kW} / \mathrm{m}^{3}$ when also balance of plant is taken into account [24].

\subsection{Ship's power plant basic description}

For the reasons explained in previous paragraphs, a fuel cell zero emission cruise ship is not feasible at the current technology's state of the art. A strong opportunity for the future is the implementation of a hybrid solution on board, that will encompass normal or dual fuel ICE, fuel cells and accumulators like batteries or supercapacitors. This solution will affect cruise ship's power plant and their general arrangement. To show, in principle, how fuel cell installation inside a ship could affect these aspects, the following discussion will take as reference a relatively small cruise ship with main characteristics shown in Table 2. Cruise ships are interesting reference points because they travel almost anywhere in the world and so in the near future they will need to comply with strict regulations about emissions. Also, it is assumed that reference ship is equipped with pod propulsion: this technology consists in propulsion units composed by a propeller directly connected to an electric motor placed inside a waterproof pod. This system is connected to the ship by a conveniently shaped support that allows horizontal rotation. With this propulsion system, space's layout inside the ship, that is called General Arrangement (GA), can be modified more easily. This is due to the fact that the vessel does not have to include a bulky propulsion electric motor room. 
Table 2. Seven Seas Voyager's characteristics

\begin{tabular}{|c|c|}
\hline Characteristic & Value \\
\hline Length & $206.5 \mathrm{~m}$ \\
\hline Beam & $28.83 \mathrm{~m}$ \\
\hline Draught & $7.05 \mathrm{~m}$ \\
\hline Tonnage & $42363 \mathrm{GT}$ \\
\hline Decks & 12 \\
\hline Installed Power & $\begin{array}{c}4 \times \text { Wärtsilä 9L38 } \\
(4 \times 5760 \mathrm{~kW})\end{array}$ \\
\hline
\end{tabular}

Basic layout of the first three decks of a cruise ship with pod propulsion is similar to the one shown in Fig. 2, where acronyms have following meanings:

- ER: engine room, including engines, compressors, main switchboard and transformers, OFB, incinerators, garbage treatment and casings;

- WT: water treatment units, to get potable water from sea and to process waste water produced on board;

- HFO: heavy fuel oil tanks and machineries to purify fuel before introducing it in engines;

- ST: various stores;

- LAU: laundries and linen rooms;

- CREW: crew cabins and other rooms dedicated to them.

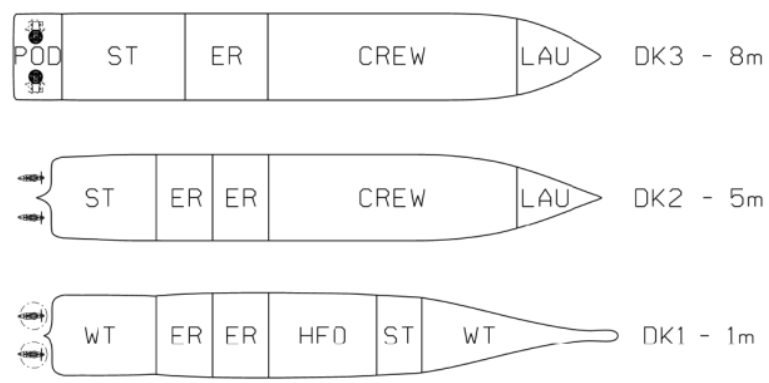

Fig. 2. GA in principle of cruise ship with POD propulsion and ICE (first three decks)

Engine room is separated by a transversal watertight bulkhead for mandatory safety reasons. Considering the case in which PEMFC are installed onboard, ship could benefit from a reduction of emissions and even a zeroemission navigation mode if sufficient fuel cell power is implemented and if the owner accepts time and speed limitation in this condition. For the cruise ship taken as reference, it is assumed to install a total of $9 \mathrm{MW}$ of fuel cells onboard to guarantee navigation without emission at a reduced speed, ideally replacing two ICEs. A configuration in principle of the first three decks of case study's ship with PEMFC on board is shown in Fig. 3. The main change between Fig. 3 and Fig. 2 is the presence of a $\mathrm{LH}_{2}$ room, where cryogenic tanks are supposed to be installed. Despite challenges related to extreme low temperatures, energy requirements for liquefaction, boiloff losses and the need of dedicated equipment not readily available for naval application, $\mathrm{LH}_{2}$ benefits of a more efficient volume utilization than compressed hydrogen without high pressure related safety issues. This space occupies two decks due to big diameter of tanks, and comprehends an allowance for related machineries.

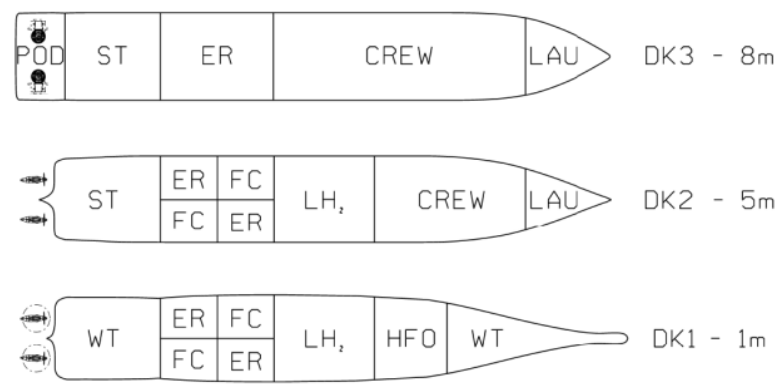

Fig. 3. GA in principle of cruise ship with POD propulsion, ICE and PEMFC (first three decks)

ER spaces have been widened on deck 3 due to the probable presence of more electric devices supporting fuel cells, in fact ship's distribution is an alternatingcurrent (AC) grid, while fuel cells generate a direct current (DC). Hydrogen and HFO tanks have been dimensioned supposing a 14 days autonomy, 10 hours of zero emission navigation and fuel cell's continuous service to power hotel load related users, like lighting, galleys, air conditioning, etc. Engine room has been ideally divided longitudinally to install in two separate rooms and on two different decks 4.5 MW of PEMFC each and in other rooms two Wärtsilä W12V32 engines (6720 kW each). Space related to HFO tanks and auxiliaries decreased up $60 \%$ (considering specific fuel oil consumptions indicated in [25]), but gains of liquid hydrogen room and a bigger engine room entails a loss of crew and store space. Crew space between deck 2 and 3 is decreased by $20 \%$, where almost 55 cabins cold have been placed. Stores on deck 1 have also been lost ( $25 \%$ of total stores previously available). These spaces should be recovered on higher decks, sacrificing part of payload.

Similar conclusions can be found analyzing the reference ship's basic GA when SOFC and dual fuel engines are installed. This design choice has been made because once LNG tanks and auxiliaries are installed onboard it's worth to use this fuel also for ICEs.

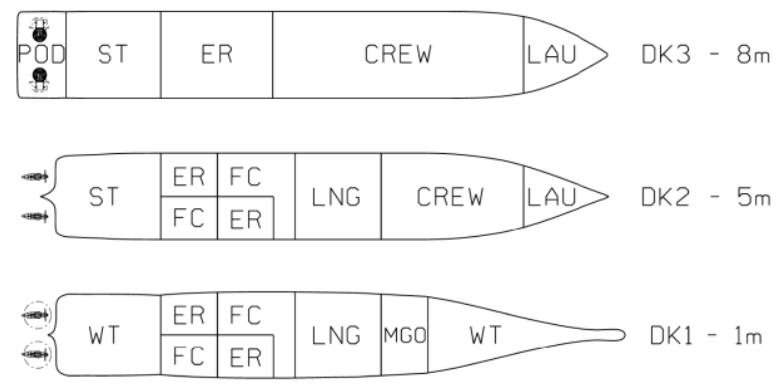

Fig. 4. GA in principle of cruise ship with POD propulsion, ICE and SOFC (first three decks)

For SOFC installation ER spaces have been widen not only at deck 3, like in Fig. 3, but also on decks 1 and 2 because SOFC power density. Even in this case ER spaces on two lower decks have been divided in four separate rooms, alternatively occupied by Wärtsilä W12V31DF dual fuel engines (6360 kW each). LNG room occupies two decks like $\mathrm{LH}_{2}$ one, but in this case 
calculations showed that less fuel volume is required, even if LNG is used both for SOFC and ICE. That's because LNG's energy density is bigger than $\mathrm{LH}_{2}$ one (about $5800 \mathrm{kWh} / \mathrm{m}^{3}$ against $2400 \mathrm{kWh} / \mathrm{m}^{3}$ ). Also space for traditional liquid fossil fuel is reduced, assuming Marine Gas Oil (MGO) is used only as pilot fuel in ICE and to reach a certain autonomy in case of emergency ("Safe Return To Port" contractual autonomy [26]). Decrease of traditional fuel space compensates widening of engine room on deck 1 , but its increase on deck 2 negatively affects crew spaces, almost with same impact showed in Fig. 3. So even in this configuration there is a loss of space available for crew and stores that must be compensated by a sacrifice of some payload. This negative aspect influences economic analysis of such investment because ship owner would not just consider increased capital cost mainly due to fuel cells and big refrigerated insulation tanks and operative cost of different fuels, but also revenue's loss due to a decrease of space available for passenger cabins or public spaces.

\subsection{Emissions reduction}

As already stated, fuel cell installation would be beneficial for emission reduction. Calculations show that reference ship with current configuration, if HFO is used as fuel, emits about 1800 tons of $\mathrm{CO}_{2}, 1.5$ tons of $\mathrm{SO}_{\mathrm{x}}$ (with scrubbers, without it would be 20 times greater), 40 tons of $\mathrm{NO}_{\mathrm{x}}$ and 3 tons of Particulate Matter (PM) in a typical 14 days cruise, using data available for typical ship emissions [27]. Two different configurations of fuel cell implementation onboard bring different benefits on emissions, as shown in Table 3. Calculations have been performed assuming that electrical users are the same for current ship and new layouts. Particularly, installing PEMFC leads to halve overall $\mathrm{CO}_{2}, \mathrm{NO}_{\mathrm{x}}, \mathrm{SO}_{\mathrm{x}}$ and $\mathrm{PM}$ emissions: reduction is the same for each pollutant gas because it is only reduced the amount of energy transformed by ICE fueled by HFO.

Table 3. Emissions comparison between different configurations

\begin{tabular}{|c|c|c|c|c|}
\hline Situation & $\begin{array}{c}\mathbf{C O}_{2} \\
\text { [ton] }\end{array}$ & $\begin{array}{c}\mathbf{S O}_{\mathbf{x}} \\
\text { [ton] }\end{array}$ & $\begin{array}{c}\text { NOx } \\
\text { [ton] }\end{array}$ & $\begin{array}{c}\mathbf{P M} \\
\text { [ton] }\end{array}$ \\
\hline ICE (HFO) & 1800 & 30 & 40 & 3 \\
\hline $\begin{array}{c}\text { ICE (HFO) + } \\
\text { Scrubber }\end{array}$ & 1800 & 2 & 40 & 3 \\
\hline $\begin{array}{c}\text { ICE (HFO) + } \\
\text { Scrubber + } \\
\text { PEMFC (LH })\end{array}$ & $\begin{array}{c}900 \\
(-50 \%)\end{array}$ & $\begin{array}{c}1 \\
(-95 \%)\end{array}$ & $\begin{array}{c}20 \\
(-50 \%)\end{array}$ & $\begin{array}{c}1.5 \\
(-50 \%)\end{array}$ \\
\hline $\begin{array}{c}\text { ICE (DF) + } \\
\text { SOFC (LNG) }\end{array}$ & $\begin{array}{c}960 \\
(-46 \%)\end{array}$ & $\begin{array}{c}0 \\
(-100 \%)\end{array}$ & $\begin{array}{c}3 \\
(-90 \%)\end{array}$ & $\begin{array}{c}0.5 \\
(-83 \%)\end{array}$ \\
\hline ICE (DF) & $\begin{array}{c}1250 \\
(-29 \%)\end{array}$ & $\begin{array}{c}0 \\
(-100 \%)\end{array}$ & $\begin{array}{c}7 \\
(-82 \%)\end{array}$ & $\begin{array}{c}1.1 \\
(-60 \%)\end{array}$ \\
\hline
\end{tabular}

SOFC and DF engine improves different emissions in various ways. First, this solution reduces $\mathrm{CO}_{2}$, but not as much as PEMFC installation and does not allow a navigation mode with zero emissions. Using LNG as fuel has great advantages in term of other emissions considered in this work and particularly it eliminates $\mathrm{SO}_{\mathrm{x}}$ and strongly reduces $\mathrm{NO}_{\mathrm{x}}$ and $\mathrm{PM}$ emissions, without adopting specific abatement devices [28]. Even a power plant composed only by DF ICE emits less $\mathrm{NO}_{\mathrm{x}}$ and PM then the proposed solution with PEMFC and ICE burning HFO.

\section{Conclusions}

In these years, attention to fuel cells application in maritime sector is growing rapidly, mainly for stricter regulations about emissions. A big obstacle to future fuel cells implementation on board is given by the lack of internationally recognized standards and regulations about these technologies, leaving designers with few indications about safety measure that must be installed in order to have a ship at least as safe as one with traditional power sources. In this paper, two different types of fuel cells have been considered. PEMFCs, fed by pure hydrogen and with good power density, allow operating a ship without emissions if a sufficient power is installed, but this technology limits possibility to recover heat for hotel and other loads. SOFC can be fed also by $\mathrm{LNG}$ and operate at high temperature that facilitates heat recovery and therefore higher overall efficiency can be expected. On the other hand, SOFC has lower power density and their emissions depend on the fuel utilized. It has been observed that if PEMFC or SOFC are installed on board, they increase space occupied by machinery rooms, fuel tanks and related auxiliaries at the expense of less space for stores and crew cabins that will affect the total payload capacity of the ship.

\section{References}

1. O. Edenhofer, R. Pichs-Madruga, Y. Sokona et al., Climate Change 2014 - Mitigation of Climate Change, 9 (2014)

2. United Nations Conference on Trade And Development (UNCTAD), Review of maritime transport 2017, Ch. 2, 23-40 (2018)

3. International Maritime Organization, Third IMO GHG Study 2014, 6-17 (2015)

4. C. Deniz, B. Zincir, Environmental and economical assessment of alternative marine fuels in Journal of Clean Production, 113, 438449 (2016)

5. International Maritime Organization, Resolution MEPC.304(72), Annex 11 (2018)

6. M. Launes, Norwegian parliament adopts zero-emission regulations in the fjords, maritimecleantech.co (2018)

7. L. van Biert, M. Godjevac, K. Visser, P.V. Aravind, A review of fuel cell systems for maritime applications, Journal of Power Sources 327, 345-364 (2016)

8. T. Tronstad, H. Høgmoen Åstrand, G. P. Haugom, L. Langfeldt, Study on the use of fuel cells in shipping (2017) 
9. E4Tech, The Fuel cell Industry Review 2019 (2019)

10. IMO, Resolution MSC.391(95) (2015)

11. Nippon Kaiji Kyokai (Class NK), Guidance for Liquefied Hydrogen Carriers (2017)

12. American Bureau of Shipping, Guide for Fuel cell power systems for marine and offshore applications (2019)

13. Bureau Veritas, Guidelines for Fuel Cell Systems On-board Commercial Ships (2009)

14. DNV GL, Rules for classification of ships: Part 6 Ch. 2 Sec. 3 (2018)

15. Korean Register of Shipping, Guidance for Fuel Cell Systems on Board of Ships (2015)

16. Registro Italiano Navale (RINA), Rules for Fuel Cells Installation in Ships (FC-SHIPS) (2018)

17. H. Schneekluth, V. Bertram, Ship Design for Efficiency and Economy, Ch. 1, 5-12 (1998)

18. Web journal article: "Why More LNGPowered Cruise Ships Are Being Built", visited on 11/05/2020, available at: https:/www.hellenicshippingnews.com/whymore-lng-powered-cruise-ships-are-beingbuilt/

19. Battelle Memorial Institute, Manufacturing Cost Analysis of 100 and $250 \mathrm{~kW}$ Fuel Cell System for Primary Power and Combined Heat and Power Application, Ch. 7, 87-97 (2016)

20. G.W.C. Kaye and T.H. Laby, "Tables of Physical and Chemical Constants", 124 (1986)

21. J. Larminie, A. Dicks, Fuel Cell Systems Explained, Appendix 2.2, 396-400 (2003)

22. A. Molland, The maritime engineering reference book: a guide to ship design, construction and operation, Ch. 6, 427 (2008)

23. R. Taccani, F. Ustolin, N. Zuliani, P. Pinamonti, A. Pietra, Fuel Cells and Shipping Emissions Mitigation, Technology and Science for the Ships od the Future, 885-892 (2018)

24. Datasheet: "Bloom Energy Server ES5$200 \mathrm{~kW}$ " by Bloom Energy, visited on 12/05/2020, available at:

https://www.bloomenergy.com/datasheets/ene rgy-server-es5-200kw

25. Web Page: "Regent Seven Seas Cruises: find a cruise", visited on 13/05/2020, https://www.rssc.com/cruises?sh=VOY

26. Datasheet: "Wärtsilä 32 product Guide" by Wärtsilä, visited on $13 / 05 / 2020$, available at: https://www.wartsila.com/docs/defaultsource/product-files/engines/msengine/product-guide-o-ew32.pdf?utm source $=$ engines\&utm medium $=$ dieselengines\&utm_term $=$ w32\&utm_content =productguide\&utm_campaign $=$ msleadscorin $\mathrm{g}$

27. International Maritime Organization, Resolution MSC.216(82), Regulation 21 (2006)

28. European Commission, Quantification of emissions from ships associated with ship movements between ports in the European Community, Ch. 2 (2002) 